\title{
THE SOUTH AFRICAN STRATEGIC AND OPERATIONAL OBJECTIVES IN ANGOLA, 1987-88
}

\author{
Leopold Scholtz ${ }^{1}$ \\ Department of History, Stellenbosch University
}

\begin{abstract}
Ever since 1988, a war of words has been waged about the question who won the so-called Battle of Cuito Cuanavale - the SADF, or the Cuban and Angola forces. A lot depends, of course, on what the South Africans' strategic and operational objectives were, and whether they reached these or not. On a somewhat lower level, the debate has centred on the question whether the SADF wanted to occupy Cuito Cuanavale. If they did, it becomes easier to argue that South Africa was dealt a heavy reverse there; if not, such an argument becomes more difficult to sustain. In this article, South Africa's strategic and operational objectives are analysed, based on archival sources. The basic conclusions are that the South African government was realistic enough to see that it could not replace the MPLA with UNITA by force, although it was hoped this might happen through elections. As far as Cuito Cuanavale is concerned, the sources are unequivocal: Although the occupation of the town was indeed discussed, it was never seriously considered. The objective was simply to drive FAPLA over the Cuito River, to prepare the riverbank as a defensive line, to turn it over to UNITA and then to pull back. By far most of the South Africans' objectives were reached.
\end{abstract}

\footnotetext{
${ }^{1}$ Dr Leopold Scholtz is at present correspondent for Media24's newspapers in Europe. He served several terms as professor extraordinaire in the History Department at the University of Stellenbosch and continues as Research Fellow at the same university. He is the writer or co-writer of four books and nearly forty academic articles. He holds the rank of captain (infantry) in the SA Army Reserve Force.
} 


\section{Introduction}

During 2007-08, with the 20th commemoration of the so-called Battle of Cuito Cuanavale, a rather heated public exchange took place between the - to simplify things - supporters of the old South African Defence Force (SADF) and those of the Cuban and Angolan forces in the conflict. The question "who won the battle" was the main bone of contention. ${ }^{2}$

In this debate, which has simmered for some years, people like Generals Jannie Geldenhuys and Magnus Malan, Chief of the SADF and Minister of Defence respectively at the time, and Mr Pik Botha, Minister of Foreign Affairs in the then government, contended that the SADF had won. They were seconded by writers like Helmoed-Römer Heitman, Fred Bridgeland and Willem Steenkamp. ${ }^{3}$ On the other hand, Cuban dictator Fidel Castro, MK veteran and later ANC cabinet member Ronnie Kasrils, Italian-American historian Professor Piero Gleijeses and several other politicians and academics took issue with that and reasoned that the Cubans and Angolans had not only dealt the SADF a heavy blow at Cuito Cuanavale, but that they, in fact, broke the back of the apartheid government and thus paved the way for the transition of $1994 .^{4}$

${ }^{2}$ Vide Ronnie Kasrils: "Turning point at Cuito Cuanavale", in Sunday Independent, 23.3.2008; Piero Gleijeses: "Cuito Cuanavale revisited", in Mail \& Guardian, 9.7.2007; Jannie Geldenhuys: "Veterane van die koue oorlog, insluitend die diensplig-generasie, oor waarheid en propaganda, at www.news24.com/Rapport/InDiepte/0,,752-2462_2447895,00.html).

3 Jannie Geldenhuys' viewpoint is expressed in Willem Steenkamp: South Africa's Border War (Gibraltar, Ashanti, 1990), p. 152; Marga Ley: "Jannie Geldenhuys: 'Ek en Castro het nie saamgesweer'" (Beeld, 12.11.1992); Jannie Geldenhuys: Dié wat gewen het. Feite en Fabels van die Bosoorlog, $2^{\text {nd }}$ ed. (Pretoria, Litera, 2007), pp. 179 and 191; and Jannie Geldenhuys: South Africa is fantastik (Pretoria, Protea, 2007), pp. 129-137. Magnus Malan's contribution is to be found in his memoirs, My Lewe saam met die SA Weermag (Pretoria, Protea, 2006), pp.272-273. Vide further HelmoedRömer Heitman: War in Angola. The Final South African Phase (Gibraltar, Ashanti, 1990); Fred Bridgeland: The War for Africa. Twelve Months that Transformed a Continent (Gibraltar, Ashanti, 1990).

${ }^{4}$ Cf. Ronnie Kasrils: "Turning point at Cuito Cuanavale" (Mail \& Guardian, 23.4.2008); Fidel Castro: My Life (London, Penguin, 2007); "Fidel on $30^{\text {th }}$ anniversary of the Battle of Cuito Cuanavale, Angola \& more", at www.itsabouttimebpp.com/Announcements/Fidel_on_30th_Anniversary.htm 1; Paulo Jorge: "Presentation by Comrade Paulo T. Jorge in the ceremony of commemoration of the $20^{\text {th }}$ anniversary of the Battle of Cuito Cuanavale", at www.pmpsa.gov.za/FILES/pdfs/mpla.pdf; Isaac Saney: "African Stalingrad: 
On a somewhat lower level, the debate centred on the question whether the Cubans and Angolans thwarted a SADF attempt to capture the town of Cuito Cuanavale, or whether the South Africans actually intended to take the town in the first place. After all, if Cuito Cuanavale were indeed the South Africans' intended objective, this would mean that they suffered a reverse. Moreover, if the South Africans never wanted possession of the town in the first place, it becomes more difficult to argue that the SADF was defeated. The more ambitious the South African objectives were, the better it may be argued that they were routed. The more limited the objectives were, the more difficult it becomes to sustain this argument. Conversely, of course, the same applies to the Cuban and Angolan governments and their objectives.

The best way to find an answer would be to establish exactly what the South African strategic and operational objectives were and to what extent the SADF reached them. This may be done best by consulting the original SADF and Foreign Office documents. The most important of these were recently published on the internet by the Veterans' Association of 61 Mechanised Battalion Group (61 Mech) $;^{5}$ Aluka, which describes itself as "an international, collaborative initiative building an online digital library of scholarly resources from and about Africa"; ${ }^{6}$ and Digital Innovation South Africa (Disa), "a national collaborative initiative undertaking the building of an online, high quality information resource containing historical material". These web pages are, after registering, accessible to serious academic researchers. Of course, there are more documents in the Documentation Centre of the SANDF, but many are still classified, and getting them declassified is a long and arduous process. The Cuban and Angolan documents are not freely available (Gleijeses is the only historian ever to be granted access to the Cuban archives), so one has to rely on secondary sources. On this outcome, one may then base a conclusion.

The Cuban revolution, internationalism and the end of apartheid" (Latin American Persepctives 33/81, 2006), pp. 81-117; Horace Campbell: "The Military Defeat of the South Africans in Angola" (Montly Review, April 1989, pp. 1-15); Edgar J. Dosman: "Countdown to Cuito Cuanavale: Cuba's Angolan campaign", in Gary Baines \& Peter Vale (eds.): Beyond the Border War. New Perspectives on Southern Africa's Late-Cold War Conflicts (Pretoria, University of South Africa, 2008, pp. 207-228.

${ }^{5}$ Cf. www.61mech.org.za.

${ }^{6} \mathrm{Cf}$. www.aluka.org/page/about/historyMission.jsp.

${ }^{7} \mathrm{Cf}$.

www.disa.ukzn.ac.za/index.php?option=com_content $\& v i e w=\operatorname{article} \& i d=44$ \&Itemid=61. 


\section{The background}

In order to understand South Africa's strategic and operational aims, it is necessary to start with Operation Savannah, South Africa's ill-fated intervention in the Angolan civil war in 1975-76. Cuba's dictator Fidel Castro's interpretation was that the South Africans wanted "to rob the Angolan people of its legitimate rights and install a puppet government" and that their aim was "dismembering Angola and robbing it of its independence". ${ }^{8}$ In fact, the South African objectives were rather modest. Having been urged to intervene by the USA, Zaire, Liberia, Zambia, the Ivory Coast and Senegal, the strategic aim was to put UNITA in a strong position when negotiating - as the Alvor Agreement between the three Angolan freedom movements, the MPLA, the FNLA and UNITA, stipulated - about an interim government of national unity preceding free elections. To this end, the South African military was hesitantly and incrementally tasked at first to give weapons to UNITA, then to train UNITA fighters to operate them, and finally to help occupy UNITA's traditional heartland in southern Angola and then to withdraw. In the event, when independence day dawned on 11 November 1975, UNITA was not yet firmly ensconced in the south, and the decision was taken to stay on for the time being. However, international support for South Africa evaporated, and the isolated Pretoria government finally had to withdraw. ${ }^{9}$ The MPLA was internationally acknowledged as government of Angola, the FNLA withered away, and UNITA battled on in an insurgency war.

This was a rather traumatic experience for the South Africans, who felt that they were left in the lurch after having done others' dirty work. This played a definite role in the 1987 campaign, as we shall see.

During the years 1978-87, the South African Defence Force (SADF) launched a series of trans-border operations. These were in principle quite different from Operation Savannah in that they were primarily aimed at the Namibian insurgency movement SWAPO, which used Angolan territory to infiltrate southwards over the border. In these operations, SWAPO was systematically pushed northwards, further from the border, in order to make its insurgency more difficult and to disrupt its operations before they could begin. By the beginning of 1984, the SADF was, in the words of Colonel Jan Breytenbach, "in control of Cunene

\footnotetext{
${ }^{8}$ Speech by Fidel Castro, 2.12.2005, at emba.cubaminrex.cu/Default.aspx?tabid=15937.

${ }^{9}$ F. du Toit Spies: Operasie Savannah 1975-1976 (Pretoria, SADF Directorate Public Relations,, 1989), Ch. 6-7 and 12; Sophia du Preez: Avontuur in Angola. Die Verhaal van Suid-Afrika se Soldate in Angola 1975-1976 (Pretoria, J.L. van Schaik, 1989), Ch. 2.
} 
Province east of the Cunene River and as far north as Cassinga". ${ }^{10}$ This meant that the SADF controlled almost the entire area up to the railway between Namibe and Menongue.

During these operations, the South Africans also clashed with FAPLA, the Angolan Army, but this was a by-product, not their main aim. South Africa also gave military aid in the form of weapons, training and advice to UNITA, and at times even gave them air support. ${ }^{11}$ Nevertheless, in spite of a large-scale and continuous SADF presence in the south of Angola, the South Africans did not see themselves as actors in the civil war between the MPLA and UNITA. Their concern was primarily to prevent SWAPO insurgents from entering Namibia.

In 1984, the so-called Lusaka Accord was signed between South Africa and Angola, in which the SADF withdrew from Angola in exchange for a promise that the MPLA would prevent SWAPO insurgents from infiltrating into Namibia. SWAPO was not a party to the agreement and so never stopped its fighters going southwards, but the MPLA did nothing to restrain them either, as it had promised. Although the SADF launched several more cross-border operations in 1984-86, these were small in scale and did not penetrate deep.

During the last months of 1986, a decision was apparently made to hit SWAPO again. The South African Army received an order to move into the socalled Fifth Military Region of Angola (that is Cunene Province in the southwest) and drive SWAPO back to where they were before the Lusaka Accord. This order was, however, rapidly overtaken by news of a massive FAPLA offensive against UNITA in the Sixth Military Region further eastwards. The decision was thus taken to "stabilise" the situation here first as it could be detrimental to the war against SWAPO in the Fifth Region. ${ }^{12}$ In the event, the plan was overtaken by events and never carried out.

\section{The South African strategic objectives}

\footnotetext{
${ }^{10}$ Jan Breytenbach: The Buffalo Soldiers. The Story of South Africa's 32 Battalion 1975-1993 (Alberton, Galago, 2003), p. 247.

${ }^{11}$ Cf. Edward George: The Cuban Intervention in Angola, 1965-1991 (London, Frank Cass, 2005), p. 169.

${ }^{12} 61$ Mech, "Voorligting aan senior offisiere van die SAW oor Operasie Moduler/Hooper", n.d., paragraph 7, at www.61mech.org.za/assets/files/mediafiles/43a13db287e52e92019a07ba292 87ca33a2ceb00_1.pdf.
} 
During the seventies and eighties, the South African government viewed the USSR as the big threat, with Cuba as its surrogate. As President PW Botha's biographer explained:

The Botha Government viewed the world in terms of an international power struggle, waged primarily between the Communist bloc and the so-called free world. South Africa was a target in the Soviet strategy ... The RSA was thus seen to be engaged in a total war, with a total onslaught on all the power bases of the State. Total war was seen as a fully-fledged, undeclared war to destroy the RSA, which influenced, besides the military dimension, each facet of society. Against that the RSA's only solution was to follow a total strategy. ${ }^{13}$

Botha's Minister of Defence, General Magnus Malan, explicitly pointed his finger at Angola, Mozambique and Zimbabwe, as well as at SWAPO and the ANC, as "puppets" of the Soviet Union. These had the intention "to win South Africa for the communists", as Malan wrote in his memoirs. ${ }^{14}$

Whether this was an accurate analysis on not, is beside the point. In general, the government was of the opinion that South Africa was engaged in a "struggle for survival" (oorlewingstryd).${ }^{15}$ Whoever wants to understand the South African security strategy during the seventies and eighties, must take the government's fear of the Soviet Union seriously. Rightly or wrongly, that was the South African government's point of departure. The security strategy was in other words in principle defensive. ${ }^{16}$

The South African government's stance on Namibia and Angola flowed from this. As Pik Botha wrote to his US counterpart, Alexander Haig, South Africa strove for an internationally recognised independence for Namibia "under a

${ }^{13}$ Daan Prinsloo: Stem uit die Wildernis. 'n Biografie van oud-pres. PW Botha (Mosselbaai, Vaandel-uitgewers, 1997), p. 133.

${ }_{14}^{14}$ Magnus Malan: My Lewe saam met die SA Weermag, p. 194.

${ }^{15}$ Disa, Minutes of State Security Council Meeting, 28.1.1980, at www.disa.ukzn.ac.za/index.php?option=com_content $\&$ view $=$ article $\& i d=44$ \&Itemid=61.

${ }^{16}$ Cf. Disa, "Riglyne vir die Staatsveiligheidsraad om 'n langtermyn nasionale strategie ten opsigte van selfverdedigingsaksies te formuleer, bylae A", attached to minutes of State Security Council, 12.2 1979, at. www.disa.ukzn.ac.za/index.php?option=com_displaydc\&recordID $=\min 1979$ 0212.040.024.079. 
government which does not subscribe to Marxist-Leninist doctrines". ${ }^{17}$ During a visit by Haig's Deputy Secretary, Dick Clark, to South Africa in 1981, Pik Botha explained that his government was not against independence for Namibia as such. However, it was "not willing to accept a communist regime on its left flank":

SWAPO must not be allowed to win an election in South West Africa. We were not prepared to exchange a war on the Kunene for a war on the Orange ... If South West Africa would be governed by SWAPO, then a serious risk would rise that the Russians could threaten South Africa from the Territory. South Africa would then have to decide to invade the Territory in order to protect its interests. Such a situation would probably be less acceptable to the USA than the status quo. If SWAPO would govern South West Africa, Botswana would directly feel threatened, Dr Savimbi would be eliminated and South Africa would be totally encircled with Russian-inspired powers. If the entire Southern Africa then came under Russian tyranny, the strategic sea route around the Cape and its critical minerals would be lost to the West. ${ }^{18}$

In other words, independence - yes; a Communist SWAPO government no! And, therefore, the entire security strategy for Namibia was to win time in order to establish a situation in which SWAPO would lose an election. "There should be no doubt that South Africa did not want to have the red flag flying in Windhoek," Pik Botha told US assistant secretary of state Chester Crocker. ${ }^{19}$

In the view of the SADF high command, in military strategic terms this boiled down to, amongst others, the following:

- $\quad$ SWAPO must militarily be destroyed through continued offensive military pressure;

- $\quad$ host countries (that is, mainly Angola) must be forced through political and military force to withhold support for SWAPO;

${ }^{17}$ Aluka, Pik Botha - Al Haig, 19.5.1981. All the Aluka Foreign Affairs documents are available in a repository at www.aluka.org/action/doBrowse?sa=hist\&t=2067\&br=taxcollections\%7Cpart-of\%7Ccollection-minor.

${ }^{18}$ Aluka, Pik Botha - Cabinet colleagues, 23.6.1981. See repository at www.aluka.org/action/doBrowse?sa=hist\&t=2067\&br=taxcollections\%7Cpart-of\%7Ccollection-minor.

${ }^{19}$ Aluka, Minutes of a meeting between Pik Botha and Chester Crocker, 21.4.1986, p. 2. See repository at www.aluka.org/action/doBrowse?sa=hist \&t=2067\&br=taxcollections\%7Cpart-of\%7Ccollection-minor 
- the SADF should create a security situation within which a political solution may be found;

- the morale of surrogate powers (that is, Cuba) must be broken down (afgetakel word) and they must be made war weary to force them to withdraw;

- a positive internal security climate must be created for further influencing the inhabitants of SWA; and

- the present vacuum north of the border must be preserved and, where possible, extended. ${ }^{20}$

How did this all influence South Africa's view of Angola and the war between the MPLA and UNITA? In March 1979, General Malan, then still Chief of the SADF, presented two documents to the State Security Council in which a strategy regarding Angola was proposed.

The strategy made provision for the following: "The political situation in Angola must be kept as unstable and fluid as possible ..." This very aggressive thought was, however, followed by its basically defensive purpose - "to ensure the national security of SWA against the Marxist onslaught from without Angola". Therefore, the Angolan government had to be forced to "prevent SWAPO from deploying in South Angola". The document refers to a future state "when the political situation, especially in South Angola, has improved to the extent that a stable anti-communist government can be brought to power to the advantage of Southern Africa". It further states that the Angolan rebel movements - UNITA, FNLA and FLEC - "should operate under the leadership of UNITA as a united front with the end objective to create an anti-Marxist government in Angola". Against this background, South Africa also had to support UNITA, according to Malan's memorandums. $^{21}$

The fact that these documents were formally accepted by the State Security Council elevates the proposals to official, albeit clandestine policy. That is to say, this was the case in 1979. Did it move beyond paper proposals? Several considerations suggest that it did not.

${ }^{20} 61 \mathrm{Mech}$, HS OPS/309/4/Rekstok, "Notas vir motivering van uitbreiding van huidige ops optrede in S Angola", 5.4.1983, at www.61mech.org.za/assets/files/mediafiles/cc64951b141ac19df9fe9d07ba3f 384ba7936aed_1.pdf.

${ }^{21}$ Disa, Memorandum HSAW - Voorsitter van die SVR Werkkomitee, 15.3.1979, at www.disa.ukzn.ac.za/index.php?option=com_displaydc\&recordID=mem197 90315.040.024.079. Cf. also TRC Report, II, p. 55. 
First of all, the SADF's military strategy shows that all operations up to 1985 were not aimed at FAPLA, the Angolan Army, but at SWAPO. In fact, at least in one instance, the South African government warned its Angolan counterpart in diplomatic language of an impending SADF cross-border operation and ensured Luanda of South Africa's "consistent policy" that these actions were aimed "solely against SWAPO terrorists and any contact with forces of the People's Republic of Angola is avoided". 22 The first SADF operations specifically aimed at FAPLA happened only in 1985 and 1986, and then they were on a small, clandestine scale. As we shall see, the 1987 operation started the same way, suggesting that a forcible regime change in Luanda was not on the agenda.

Documents in the archive of the South African Department of Foreign Affairs tend to support this conclusion. In 1984, South African Minister of Foreign Affairs Pik Botha told US Assistant Secretary of State for Africa, Dr Chester Crocker, that peace in Southern Africa would be impossible if the Soviets took over Angola, as this would help the latter to take over the entire region. Therefore, it was necessary to achieve "reconciliation" between the MPLA and UNITA. The two had to be forced to talk to each other. ${ }^{23}$

On the face of it, it would seem that South Africa was still committed to the Alvor Agreement of January 1975, according to which the MPLA and UNITA had to form an interim government of national unity to prepare free elections. But things were not quite that simple. At times, President PW Botha and Pik Botha, actively considered the unilateral recognition of UNITA as the sovereign government of Angola, ${ }^{24}$ although this never happened. Pik Botha explained to a sympathetic Namibian Interim Government in 1985:

You can only get Cuban withdrawal if there is reconciliation in Angola. If you get reconciliation in Angola, [President José Eduardo] Dos Santos is finished. The moment they start talking to

\footnotetext{
${ }^{22}$ Aluka, SA government - Angolan government, 3.4.1981. See repository at www.aluka.org/action/doBrowse?sa=hist \&t=2067\&br=taxcollections\%7Cpart-of\%7Ccollection-minor

${ }^{23}$ Aluka, Minutes of a meeting between Pik Botha and Chester Crocker, 27.1.1984, p. 3; Aluka, Minutes of a meeting between Pik Botha and Robert McFarlane, US National Security Advisor, 8.8.1985, p. 4. See repository at www.aluka.org/action/doBrowse? $\mathrm{sa}=\mathrm{hist} \& \mathrm{t}=2067 \& \mathrm{br}=\mathrm{tax}-$ collections\%7Cpart-of\%7Ccollection-minor

${ }^{24}$ Aluka, Minutes of a meeting between Pik Botha and Chester Crocker, 31.10.1984, p. 6. See repository at www.aluka.org/action/doBrowse?sa=hist \&t=2067\&br=taxcollections\%7Cpart-of\%7Ccollection-minor
} 
UNITA leader Jonas] Savimbi, and this is dr. Savimbi's own assessment, we agree, then this present regime in Luanda is finished, and then SWAPO will be finally finished as well. ${ }^{25}$

In other words, the South Africans were in favour of "reconciliation", of talks between the MPLA and UNITA in the hope of replacing the Marxist MPLA with the friendly UNITA by peaceful means. Not that the South Africans had very much hope of this happening; they and the Americans agreed, "no Angolan party can achieve an outright military victory". If the Cubans were withdrawn, they thought that UNITA could control maybe $60-70 \%$ of Angola; less if the Cubans stayed on. ${ }^{26}$

The picture emerging from all of this, is that South Africa would very much prefer a friendly, anti-communist government under the leadership of UNITA in power in Luanda. Malan's very aggressive stance of 1979, however, was never implemented. It seems as if the South Africans were realistic enough to see that they did not have the military means to topple the MPLA.

In the meantime, the presence of some 30000 Cuban troops in Angola obviously complicated matters. Fidel Castro, we now know, intervened in this country in 1975 on his own initiative and without informing the Soviets, much less asking their permission. ${ }^{27}$ Thereafter, Castro's main reason for staying on was to "protect" the Angolan revolution from the "racist" South Africans, and not so much to help the MPLA win its struggle with UNITA, which he viewed as an internal affair. $^{28}$

Predictably, this is not how the South Africans - or the Americans, for that matter - saw it. In SADF documents, the Cubans are often referred to as "surrogate forces". And, therefore, South Africa and America concluded an informal pact in 1981 to demand the departure of the Cubans from Angola as a prerequisite for the

\footnotetext{
${ }^{25}$ Aluka, Minutes of a meeting between Pik Botha and the Namibian Interim Government, 21.5.1985, p. 11. See repository at www.aluka.org/action/doBrowse?sa=hist \&t=2067\&br=taxcollections\%7Cpart-of\%7Ccollection-minor

${ }^{26}$ Aluka, Minutes of a meeting between SA and US delegations, 17-18.3.1983, paragraph 6 . See repository at www.aluka.org/action/doBrowse?sa=hist\&t=2067\&br=taxcollections\%7Cpart-of\%7Ccollection-minor

${ }^{27}$ Piero Gleijeses: Conflicting Missions. Havana, Washington, Pretoria (Alberton, Galago, 2003), p. 307.

${ }^{28}$ Piero Gleijeses: "Moscow's Proxy? Cuba and Africa 1975-1988" (Journal of Cold War Studies, 8/2, Spring 2006, p. 25.
} 
SADF's withdrawal from Angola and the implementation of Namibian independence - the much-maligned concept of linkage. ${ }^{29}$ In view of the perceived Cuban/Soviet threat, the South Africans definitely saw their military presence in Angola and Namibia as defensive in nature. ${ }^{30}$ As General Malan - then still Chief of the SADF - explained in 1979 at a meeting of the State Security Council,

[t]he question was whether we are going to implement a forward defensive strategy or a close strategy. We want to ensure the RSA's national security outside the RSA ... If we look at the Rhodesian front, the Mozambican front and the Angolan front, we see that the crisis is coming. The most forward defence line should be outside the Republic. We should be able to choose the time and place. ${ }^{31}$

PW Botha, then still Prime Minister, agreed. As long as he was Prime Minister, he assured the meeting, "he was not going to engage South Africa's battle on its own territory. We now know what the Russian intentions are and that they have the ability to bring troops quickly to Southern Africa" ${ }^{\text {"32 }}$ - a reference to the influx of Cuban troops into Angola in 1975.

If one discounts the South African intervention in Angola in 1975-76, the former's military involvement in that country up to 1987 was firmly aimed at SWAPO, with the MPLA's war with UNITA a distinct afterthought. In 1985, however, a huge FAPLA (the MPLA's army) offensive against UNITA threatened to suck in the SADF. UNITA could not withstand the onslaught, and requested South African help. Very reluctantly, the South African government sanctioned the clandestine use of artillery and three 32 Battalion rifle companies to prevent Mavinga from falling. An air strike was also carried out. This was sufficient to stop the FAPLA offensive in its tracks and, although rumours abounded, nobody at the time could prove any SADF involvement. In 1986, a similar situation developed. ${ }^{33}$

\footnotetext{
${ }^{29}$ Pik Botha described the agreement in some detail to his Cabinet colleagues. Cf Aluka, Pik Botha - Cabinet colleagues, 23.6.1981. See repository at www.aluka.org/action/doBrowse?sa=hist\&t=2067\&br=taxcollections\%7Cpart-of\%7Ccollection-minor

${ }^{30}$ Aluka, Minutes of a meeting between SA and Angola, 7.12.1982, passim. See repository at www.aluka.org/action/doBrowse?sa=hist\&t=2067\&br=taxcollections\%7Cpart-of\%7Ccollection-minor

${ }^{31}$ Disa, Minutes of the State Security Council, 28.1.1980, at www.disa.ukzn.ac.za/index.php?option=com_displaydc\&recordID $=\min 1980$ 0128.040.024.080.

${ }^{32}$ Ibid.

${ }^{33}$ Heitman: War in Angola, pp. 17-19; Bridgeland: The War for Africa, pp. 15-16; Breytenbach: The Buffalo Soldiers, pp. 255-257.
} 
These examples must have played a role when decisions had to me made in the course of 1987 about how to counter yet another FAPLA offensive.

At about the same time, a secret assessment from within the United Nations was leaked to the South African embassy in New York. According to this, the Soviet Union's objective was to entice the SADF into coming to UNITA's aid, thereby over-extending itself and creating an "escalating Vietnam type of situation from which South Africa will find it increasingly difficult to disengage". This would also increase the internal unrest in South Africa's black townships, according to Soviet strategists, which could make Pretoria more amenable to a SWAPO government in Windhoek. "Therefore, the pressure on Pretoria's ally UNITA must not only be maintained, but increased." ${ }^{, 34}$ No doubt this secret assessment stayed in the backs of the decision-makers' minds when things started to heat up again in 1987.

\section{The South African operational objectives}

During March 1987, it became clear to South African Military Intelligence that something was brewing in Angola. Tons of military supplies were being stockpiled at Tumpo, just across the Cuito River from Cuito Cuanavale, and everything pointed to a large offensive looming. Military Intelligence's assessment was that Cuito Cuanavale was being developed as a base area for an offensive against Mavinga, which would then in turn be developed as a base area for an offensive against UNITA's HQ at Jamba. ${ }^{35}$

With the debacle of 1975-76 still fresh in their memory, and also probably bearing in mind the 1985 secret UN assessment of Soviet strategy as well as the examples of the abortive FAPLA offensives of 1985 and 1986, the South African government was loath to get sucked into the Angolan civil war. Their war was with SWAPO; the struggle between the MPLA and UNITA was important only as far as it had an influence on the war with SWAPO and South Africa's own security. The South African government therefore took its refuge once again in a limited, clandestine operation. The offensive started on 14 August and, although the Angolan troops advanced very slowly - only about $4 \mathrm{~km}$ a day - it soon became clear that

\footnotetext{
${ }^{34}$ Aluka, Pik Botha - Cabinet colleagues, 8.11.1985. See repository at www.aluka.org/action/doBrowse?sa=hist\&t=2067\&br=taxcollections\%7Cpart-of\%7Ccollection-minor

${ }^{35} 61$ Mech, "Voorligting aan senior offisiere van die SAW oor Operasie Moduler/Hooper", n.d., paragraph 4, at www.61mech.org.za/assets/files/mediafiles/43a13db287e52e92019a07ba292 87ca33a2ceb00_1.pdf.
} 
more aid was needed. The order came from above: "The SADF's objective/order is to support UNITA to stop an offensive against Mavinga." 36

Meanwhile, staff officers were working overtime to prepare plans and alternatives. According to Fred Bridgeland, some colonels in the field strongly suggested making the main thrust of the SADF advance northwards west of the Cuito River instead of to the east, where the FAPLA offensive was developing. This would have the advantage of hitting the enemy in his back areas where he was weak and where he did not expect it. ${ }^{37}$

This idea was indeed discussed in staff planning papers. In a document dated 5 June where the thinking at SADF General Headquarters was set out, it was stated that an attack on Menongue "would militarily probably solve the problem"38. This would, however, mean a major operation for which the Army's manpower was not adequate. ${ }^{39}$ Besides, the "central idea is to have the offensive fail without the RSA being committed totally". An attack on Cuito Cuanavale was also considered and discarded as this also would have meant a major operation; the idea was still a clandestine, limited operation. ${ }^{40}$

Definite operation instructions were then issued by the Chief of the SADF and the Chief of the Army. Taken together, the decision was that a force of about 80 members of the Reconnaissance Commandos would aid UNITA with anti-aircraft and anti-tank weapons. Two rifle companies from $32 \mathrm{Bn}$ and a Valkyrie rocket battery were also sent in with the express order that they could only be used defensively, and then only if and when FAPLA reached a certain line. If none of these did the trick, SAAF air strikes were allowed - but UNITA was emphatically not to be told beforehand about this. These strikes were not to be undertaken against infrastructure targets or FAPLA fortresses. In addition, all operations were to be presented as UNITA operations, and none should have been traceable back to the SADF. No personnel or equipment should be lost, and $61 \mathrm{Mech}$, the Army's most

${ }^{36}$ Ibid., paragraph 8.

${ }^{37}$ Bridgeland: The War for Africa, p. 32.

${ }^{38}$ Helmoed-Römer Heitman reports that General Jannie Geldenhuys had told him even during the war that he (Geldenhuys) had personally scuppered all ideas of moving on Menongue. (Personal communication, 30.12.2009.)

${ }^{39}$ The SADF struggled throughout the seventies and eighties with a manpower problem. Vide Merran Willis Phillips: "The End Conscription Campaign 1983-1988. A Study of White Extra-Parliamentary Opposition to Apartheid" (unpublished MA thesis, Unisa, 2002), pp. 6-22.

${ }^{40} 61 \mathrm{Mech}$, H Leër/D OPS/309/1 Op Modular, 5.6.1987, paragraph 5, at www.61mech.org.za/assets/files/mediafiles/40cc903636348751e4d8264c162 60045460d5ac6_1.pdf. . 
potent conventional warfare unit, was not to be utilised at all. ${ }^{41}$ The order remained strict, as General Geldenhuys wrote to the Chief of the Army, Lieutenant General Kat Liebenberg: "Where possible, operations are to be undertaken as Unita operations and possible tracking to RSA kept to a min[imum].,"42

The hesitant and incremental nature of the SADF involvement notwithstanding, the South African strategists were clear in their minds about why they were coming to UNITA's aid. UNITA occupied the whole of Southeastern Angola, which meant that SWAPO insurgents could not infiltrate the Kavango and Caprivi regions. This meant in turn that the insurgency south of the border in Namibia by and large remained confined to the relatively limited area of Ovamboland, which made the SADF's counterinsurgency effort that much easier. At the beginning of September, permission was therefore given for 32 Battalion, augmented by elements from 101 Battalion, to be utilised offensively, and 61 Mech was finally released and authorised to advance to Mavinga. All these forces were grouped under a single tactical HQ, 20 Brigade. $^{43}$

This resulted in a series of fierce battles around the Lomba River, where the Angolan offensive was smashed by the two SA Army units and SAAF air strikes. As the study on which this article is reporting, was not concerned with tactical aspects, it would be sufficient to state that FAPLA was reeling back in disarray by the first week of October. A very important stage in the operation was then reached and the question was: How do we continue now?

${ }^{41}$ Ibid., paragraph 11, at

www.61mech.org.za/assets/files/mediafiles/40cc903636348751e4d8264c162 60045460d5ac6_1.pdf; 61 Mech, HSAW Opsinstruksie 11/87: Op Walene, 17.6.1987, at www.61mech.org.za/assets/files/mediafiles/d09e9cc49a1475c4b535a7a3ce8 17a0cf3d2e12f_1.pdf; 61 Mech, H Leër D/OPS/309/1, Op Instr 18/87: Op Moduler, 22.6.1987, at www.61mech.org.za/assets/files/mediafiles/0a00efa4afdebe7bf164c7d30c24 9a677d7b1428_1.pdf.

${ }^{42} 61 \mathrm{Mech}$, CSADF - C Army, 7.9.1987, at www.61mech.org.za/assets/files/mediafiles/b18b40e50be397d9bad1d095676 4350393b469af_1.pdf.

${ }^{43} 61$ Mech, "Voorligting aan senior offisiere van die SAW oor Operasie Moduler/Hooper", n.d., paragraph 9 and 16; 61 Mech: HQ 20 Bde - C Army and GOC SWATF, n.d., at www.61mech.org.za/assets/files/mediafiles/43a13db287e52e92019a07ba292 87ca33a2ceb00_1.pdf. 
On the basis of original documents, several researchers state that President PW Botha, accompanied by Generals Magnus Malan, Jannie Geldenhuys, Kat Liebenberg an others, visited 20 Brigade HQ on the night of 28 to 29 September - in other words, even before the final FAPLA defeat on 3 October. After being fully briefed, Botha decided to escalate the South African involvement considerably. He therefore approved a counteroffensive to destroy the FAPLA forces east of the Cuito before the onset of the rainy season. FAPLA had to be hit so hard that it would not be able to launch another offensive before the end of $1988 .^{44}$

This was a clear departure from the original political limitations put on the SADF's actions. It is not entirely clear whether Botha still thought that the operation could be kept out of the world press. If so, it was exceedingly naïve.

Nevertheless, even before Botha's decision senior officers were already thinking about the future. Once again the question arose whether any further advance northwards should be west of the Cuito (in other words, behind FAPLA's back), or east (in FAPLA's face). In a planning paper, General Liebenberg took the position that present force levels - that is, 32 Battalion and $61 \mathrm{Mech}$ - were not sufficient to take the initiative; more was needed. He outlined three options:

- Maintaining present force levels while engaging FAPLA on the Lomba line. UNITA could then move into FAPLA's back areas to disrupt their logistics, forcing them to withdraw;

- Present forces maintained east of the Cuito, while an additional brigade had to assemble to combine with UNITA, advance west of the river northwards and take Cuito Cuanavale until FAPLA east of the river was destroyed. Then Cuito Cuanavale would be held by UNITA;

- As in the second option, but with the difference that the western force only threaten Cuito Cuanavale instead of occupying it, to force FAPLA to pull back troops to defend the town. ${ }^{45}$

Based on these ideas, Liebenberg decided on a course of action in three phases. All plans to take Cuito Cuanavale seems to have been dropped or put on ice, as several additional planning documents coming from his office subsequently contain no further reference to it.

${ }^{44}$ Heitman: War in Angola, pp. 71-72; Andreas Velthuizen: “The significance of the Battle for Cuito Cuanavale: Long-term foresight of the current strategic landscape" (Scientia Militaria 37/2, 2009, p. 113).

${ }^{45} 61$ Mech, H Leër/D OPS/309/1 Op Moduler, "Voorstelle mbt voortgesette deelname aan Op Moduler, 25.9.1987, at www.61mech.org.za/assets/files/mediafiles/6225de406de82c3c72d7a4b1f27 6e29706079934_1.pdf. 
The first phase, stopping the FAPLA offensive, was considered already finished. In the second, FAPLA's forces had to be engaged so that they could not withdraw northwards, while the enemy's logistics would be disrupted in cooperation with UNITA. It was decided to call in reinforcements in the form of 4 SA Infantry Battalion (4 SAI). Contrary to what its name suggests, this formation was, like 61 Mech, a mixed-arms unit with two mechanised infantry companies, an armoured car squadron and an artillery battery. For this operation, a tank squadron was attached as well. The expressed aim with this force, together with 32 Battalion and 61 Mech, was that it "should be used to destroy the FAPLA brigades east of the Cuito River, preferably before such or other forces are able to take or retake planned defensive positions east of the Cuito River". Artillery bombardments against Cuito Cuanavale were also authorised during Phase 2. Phase 3 entailed either the destruction of the FAPLA brigades or their being driven across the Cuito to the west bank. ${ }^{46}$

The first artillery bombardment of Cuito Cuanavale duly started by the middle of October ${ }^{47}$ and would continue for many months.

As far as Cuito Cuanavale is concerned, Liebenberg repeated that, to take the town, an additional brigade would be needed to advance northwards to the west of the Cuito. This would, however, take a full six weeks to organise. Without elaborating, Liebenberg added, "Cuito Cuanavale is worth a lot. To attack and occupy it must however be seen as a separate operation." 48

The commander of 20 Brigade, Colonel Deon Ferreira, appears to have concurred with the dropping of Cuito Cuanavale as a possible target. An operation to take the town, he signalled to Liebenberg, would not only need an additional brigade; the brigade would also have to include an entire tank regiment. This would go in against an announcement (by General Geldenhuys?) that the SADF's involvement was now limited to mopping-up actions. Besides, Ferreira continued,

${ }^{46} 61$ Mech, C Army - SWATF, 7.10.1987, at www.61mech.org.za/assets/files/mediafiles/44dd5d261c679039d5cef43d37b 5036b8b33da16_1.pdf; 61 Mech, "Beslissingsvoordrag aan HSAW oor voorgesette SAW deelname aan Op Moduler", n.d.

${ }^{47} 61$ Mech, "Voorligting aan senior offisiere van die SAW oor Operasie Moduler/Hooper", n.d., paragraph 26, at www.61mech.org.za/assets/files/mediafiles/43a13db287e52e92019a07ba292 87ca33a2ceb00_1.pdf.

${ }^{48} 61$ Mech, H Leër/D OPS/309/1 Moduler, "Beslissingsvoordrag aan HSAW oor voorgesette SAW deelname aan Op Moduler", n.d., at www.61mech.org.za/assets/files/mediafiles/3d30f10cb32b4d7dc821a26d2f2 5b97b6675864e_1.pdf. 
the enemy east of the Cuito was already $70 \%$ crushed and would not be able to restart an offensive in the next two years. ${ }^{49}$

This did not preclude others from still suggesting an attack on Cuito Cuanavale, but these ideas got nowhere. ${ }^{50}$ Liebenberg did authorise a clandestine operation by elements of 32 Battalion in cooperation with UNITA to move up west of the Cuito and threaten FAPLA's logistics, but the taking of Cuito Cuanavale did not figure in these plans. ${ }^{51}$

After a pause to resupply and bring 4 SAI to the front, the South African advance started. Without going into particulars, by early January the South Africans had driven the Angolans back into a small bridgehead at Tumpo, just across the river from Cuito Cuanavale. Therefore, GHQ in Pretoria opined that the order to destroy the FAPLA brigades or to drive them to the other side of the river, was not yet completed. FAPLA would have had to be physically driven out. ${ }^{52}$

Already at the beginning of December, Liebenberg prophetically questioned the wisdom of what he saw looming, namely full-frontal attacks on wellprepared Angolan defensive positions at Tumpo. ${ }^{53}$ Nevertheless, this is what was about to happen - not once, but three times. This stage marked the end of Operation Moduler and the beginning of Operations Hooper and Packer, the purpose of which was to destroy FAPLA or drive the Angolan troops westwards over the river. In Liebenberg's operation instruction, the purpose was formulated in accordance with the President's decision at the end of September, "to create a situation where

${ }^{49} 61$ Mech, HQ 20 Bde - C Army and GOC SWATF, n.d., at www.61mech.org.za/assets/files/mediafiles/43a13db287e52e92019a07ba292 87ca33a2ceb00_1.pdf.

${ }^{50}$ Cf. Heitman: War in Angola, p. 93.

${ }^{51} 61$ Mech, Anon.: "Gesamentlike militêre aksies deur die RSA en Unita magte teen FAPLA magte in die Sesde Militêre Streek van Angola vanaf Desember 1987 tot Maart 1988", paragraph 14, at www.61mech.org.za/assets/files/mediafiles/a347645f913fffde24b4d14607b0 3059bcbe06cb_1.pdf.

${ }^{52} 61$ Mech, Anon.: "Gesamentlike militêre aksies deur die RSA en Unita magte teen FAPLA magte in die Sesde Militêre Streek van Angola vanaf Desember 1987 tot Maart 1988", paragraph 3, at www.61mech.org.za/assets/files/mediafiles/a347645f913fffde24b4d14607b0 3059bcbe06cb_1.pdf.

${ }^{53} 61$ Mech, Commandant Bierman, SO1 Ops, SWATF - Colonel J.N.R. Botha, Army HQ, 8.12.1987. at www.61mech.org.za/assets/files/mediafiles/88673add70e21a4db835ab50b7e 896e1ac197cb2_1.pdf. 
FAPLA will not be able to launch another offensive for at least 1988". The guidelines contain the following very interesting sentence: "If the opportunity arises to capture Cuito Cuanavale relatively easy, planning should be done to do it." 54 This, of course, bears out General Geldenhuys' repeated assurances after the war.

In the thinking of the military powers that were, it was important to take Tumpo to prevent FAPLA from using it once again as a springboard for another offensive against Mavinga and Jamba. ${ }^{55}$ As Geldenhuys explained when he visited Tactical HQ on the night of 29 January, although the SADF could not afford to stay in Angola too long, it had to guarantee tangible advantages before pulling out. Therefore, FAPLA at the very least had to be driven over the Cuito and the river be prepared as an obstacle, and UNITA had to be put in a position where it could maintain itself militarily. ${ }^{56}$

An anonymous staff officer, chronicling the history of Operation Hooper, analysed the importance of Tumpo in the eyes of the SADF high command:

For the combined FAPLA/Cuban forces possession of Tumpo was of the utmost importance. Although the bridge over the Cuito River was already almost destroyed, control over the Tumpo area meant to the enemy a bridgehead over the Cuito River which would be of the utmost importance for a future offensive against UNITA. Furthermore, possession of Tumpo would ensure that the RSA/UNITA forces could not continue with an attack on Cuito Cuanavale. For the enemy possession of Cuito Cuanavale was more a moral prerequisite than a strategic necessity, as the town could not be occupied and held by own forces. Thus was the enemy propaganda surrounding Cuito Cuanavale however that the enemy

${ }^{54} 61$ Mech, Anon.: "Gesamentlike militêre aksies deur die RSA en Unita magte teen FAPLA magte in die Sesde Militêre Streek van Angola vanaf Desember 1987 tot Maart 1988", paragraph 40 (containing full operation instruction from C Army, 11.12.1987), at www.61mech.org.za/assets/files/mediafiles/a347645f913fffde24b4d14607b0 3059bcbe06cb_1.pdf.

${ }^{55} 61 \mathrm{Mech}, \mathrm{GG}(3) / 309 / 4$, GG/SG - C Med Command SWA, 23.2.1988, at www.61mech.org.za/assets/files/mediafiles/47f648e206bc1b2a567a6b71416 406faaddd70d4_1.pdf.

${ }^{56} 61$ Mech, Anon.: "Gesamentlike militêre aksies deur die RSA en Unita magte teen FAPLA magte in die Sesde Militêre Streek van Angola vanaf Desember 1987 tot Maart 1988", paragraph 367, at www.61mech.org.za/assets/files/mediafiles/a347645f913fffde24b4d14607b0 3059bcbe06cb_1.pdf. 
simply could not afford to surrender the town to the RSA/UNITA forces. For the RSA forces the occupation of Tumpo was the last stumbling block before they could regard their orders as carried out. In practice the original offensive force of the enemy was already virtually totally destroyed. ... Control over the Tumpo area however meant that the FAPLA/Cuban forces still had a bridgehead and that the pulling out of the RSA forces necessarily would lead to the reoccupation of the conquered area around Tumpo by the enemy. UNITA had to be placed in control of the key area around Tumpo to prevent a new offensive against Mavinga and Jamba for an indefinite period. $^{57}$

The SADF made three full-frontal attacks on well-prepared FAPLA and Cuban positions in the Tumpo area. In all cases, the operational instructions ordered the South African forces to force the FAPLA troops to the western side of the river. One seeks in vain for a SADF instruction to cross the river and to take Cuito Cuanavale. ${ }^{58}$ Although, it must be added, the SADF did execute deliberate movements to mislead the enemy into expecting a crossing of the river and an attack on the town itself. ${ }^{59}$ This was apparently a success, as Military Intelligence's

${ }^{57} 61$ Mech, Anon.: "Gesamentlike militêre aksies deur die RSA en Unita magte teen FAPLA magte in die Sesde Militêre Streek van Angola vanaf Desember 1987 tot Maart 1988", paragraph 512, at www.61mech.org.za/assets/files/mediafiles/a347645f913fffde24b4d14607b0 3059bcbe06cb_1.pdf.

${ }^{58}$ Cf. 61 Mech, GG/SG - C Med Command SWA, 23.2.1988, at www.61mech.org.za/assets/files/mediafiles/47f648e206bc1b2a567a6b71416 406faaddd70d4_1.pdf; 61 Mech, Anon.: "Gesamentlike militêre aksies deur die RSA en Unita magte teen FAPLA magte in die Sesde Militêre Streek van Angola vanaf Desember 1987 tot Maart 1988", paragraph 315 (containing full operational instruction to $20 \mathrm{Bde}, 16.1 .1987)$, at www.61mech.org.za/assets/files/mediafiles/a347645f913fffde24b4d14607b0 3059bcbe06cb_1.pdf; ; ibid., paragraph 368 (containing full communication by C SWATF, 28.1.1988); ibid, paragraph 529 (containng full operational instruction, 22.2.1988); ibid., paragraph 582 (containing full operational instruction, n.d.); 61 Mech, "Voorligting aan senior offisiere van die SAW oor Operasie Moduler/Hooper", n.d., pp. 40-41 and 56-57, at www.61mech.org.za/assets/files/mediafiles/43a13db287e52e92019a07ba292 87ca33a2ceb00_1.pdf.

${ }^{59}$ Cf. 61 Mech, Anon.: "Gesamentlike militêre aksies deur die RSA en Unita magte teen FAPLA magte in die Sesde Militêre Streek van Angola vanaf Desember 1987 tot Maart 1988”, paragraphs 489 and 527, at 
assessment was that FAPLA and the Cubans were clearly under the impression that the SADF was bent on the capture of the place. $^{60}$

During all three attacks, enemy air strikes, artillery fire and minefields disrupted the South African efforts almost before they started, and each time the South Africans had to pull back - just as General Liebenberg expected in December. This once again proved that such unimaginative tactics rarely succeed.

The irony was, of course, that these three attacks deviated from the Army's own battle doctrine. General Constand Viljoen, Geldenhuys' predecessor as CSADF, told Padraig O'Malley in 1998 that the Army started changing its doctrine in 1966-'67 - when he (Viljoen) was CO of the Military College - from the setpiece and very conventional WWII approach to a modern mobile warfare.

The battle at the Lomba River was "about the very first one in which we could apply our theory of mobile war which actually is based on not to hold ground but to create the design of battle in such a way that you would lure the enemy into [a] killing ground and then [with] the superiority of fire power and movement, you would kill him completely". 61

This was confirmed by a 1987 book by Colonel - later Major General Roland de Vries about mobile warfare. The basic purpose of mobile warfare, De Vries explained, was to outwit the enemy imaginatively rather than being sucked into a head-on confrontation. "Blood definitely is not the price of victory," he wrote. $^{62}$

This makes it all the more sad that the SADF ignored its own doctrine at Tumpo.

www.61 mech.org.za/assets/files/mediafiles/a347645f913fffde24b4d14607b0 3059bcbe06cb_1.pdf.

${ }^{60} 61$ Mech, "Voorligting aan senior offisiere van die SAW oor Operasie Moduler/Hooper", n.d., p. 35, at www.61mech.org.za/assets/files/mediafiles/43a13db287e52e92019a07ba292 87ca33a2ceb00_1.pdf.

${ }^{61}$ Interview by Padraig O’Malley with General Constand Viljoen, 26.7.1998, at http://www.nelsonmandela.org/omalley/index.php/site/q/031v00017/04lv003 44/05lv01183/06lv01209.htm.

${ }^{62}$ Roland de Vries: Mobiele Oorlogvoering. 'n Perspektief vir Suider-Afrika (Menlo Park, F.J.N. Harman, 1987), p. xxii. 


\section{The Cuban flanking march}

Meanwhile Cuban dictator Fidel Castro was watching events with growing frustration, as he vehemently disagreed with the FAPLA offensive to start with. Serious differences regarding the military strategy to be followed against UNITA and South Africa had become a feature of the relations between Cuba and the Soviet Union since the early eighties. In this case, the Angolans and their Soviet advisors ignored the Cuban view that an offensive would be doomed to failure, and the Cubans, therefore, did not participate at the beginning. ${ }^{63}$ (South African Military Intelligence reports that Cubans were involved with FAPLA units, ${ }^{64}$ were therefore wide off the mark.)

Castro himself explained in a speech in December 2005 that the South Africans, in his view,

... prepared to deliver a mortal blow against Angola. Desperate calls were received from the Angolan government appealing to the Cuban troops for support in fending off presumed disaster; it was unquestionably the biggest threat from a military operation in which we, as on other occasions, had no responsibility whatever. ${ }^{65}$

On 15 November 1987, after a meeting with his key advisors lasting ten hours, Castro ordered the crack $50^{\text {th }}$ Division, which normally guarded Havana, to Angola. He did not consult the Soviets, although he did inform the Kremlin a few days later. ${ }^{66}$ His motives were complex. On the one hand, according to US Assistant Secretary of State for Africa, Chester Crocker, a senior Soviet official informed the Americans already in late 1987 "that the Cubans now realized that they had to

${ }^{63}$ Piero Gleijeses: "Moscow's Proxy? Cuba and Africa 1975-1988 (Journal of Cold War Studies, 8/2, Spring 2006), pp. 31-36. Cf. also Chester Crocker, p. 360.

${ }^{64} \mathrm{Cf}$. for example $61 \mathrm{Mech}, \mathrm{H}$ Leër D/OPS/309/1, Op Instr 18/87: Op Moduler, 22.6.1987, at www.61mech.org.za/assets/files/mediafiles/0a00efa4afdebe7bf164c7d30c24 9a677d7b1428_1.pdf.

65 "Fidel on 30th Anniversary of the Battle of Cuito Cuanavale, Angola \& More", at www.itsabouttimebpp.com/Announcements/Fidel_on_30th_Anniversary.htm 1.

${ }^{66}$ Piero Gleijeses: "Moscow's Proxy? Cuba and Africa 1975-1988 (Journal of Cold War Studies, 8/2, Spring 2006), p. 37; Vladimir Shubin: The Hot 'Cold War'. The USSR in Southern Africa (London, Pluto, 2008) pp. 110-111; George: The Cuban Intervention in Angola, pp. 210-211. 
withdraw their troops from Angola". At more or less the same time, the Cuban Deputy Minister of Foreign Affairs, Ricardo Alarcan, confided to a US diplomat that

[t]he Angolans might be worried about the prospect of Cuban troop withdrawal; but no-one stood to benefit from it more than the Cubans themselves. Alarcan expanded on this theme a few days later at a lunch with an American diplomat in Havana: a settlement would enable Cuba honorably to terminate a very heavy commitment. ${ }^{67}$

This was important. The war was becoming ever more unpopular in Cuba itself, so Castro was seeking a way out. However, as he told Crocker himself a few months afterwards, Cuba was prepared to contribute to a settlement, "but not just any settlement: it must be an honorable one ..." memoirs, this "could only work if both his military and political options appeared to be credible". ${ }^{69}$ In 1989, a "very senior Cuban Army officer" visiting Simon's Town also admitted, according to Rear Admiral Chris Bennett,

that one of the factors that had finally led to Cuba supporting the termination of the conflict with South Africa, was a major Naval Exercise (Exercise Magersfontein) conducted from Walvis Bay during 1988. Of interest is that the reason for putting on this large, extremely complex and highly publicised exercise at such very short notice, was to pass the message that the SA Navy was capable of escalating the maritime aspect and could also support its fleet fully from a forward base. ${ }^{70}$

And, therefore, Castro decided on a gamble. He took over operational command all the way from Havana, forbade any retreat from Cuito Cuanavale in the direction of Menongue and dispatched the aforementioned crack formation to Angola. These troops were, however, not to reinforce the Cuito Cuanavale front, but to march west of the Cunene River southwards to the Namibian border. It was, in other words, designed to threaten to outflank the South African units at Tumpo and to threaten an invasion of Namibia.

Whatever one may think of Castro's politics, he undoubtedly has a fine military mind. Later he likened his approach to "a boxer who with his left hand

\footnotetext{
${ }^{67}$ Chester Crocker: High Noon in Southern Africa. Making Peace in a Rough Neighborhood (Johannesburg, Jonathan Ball, 1992), pp. 361-362.

${ }^{68}$ Crocker: High Noon in Southern Africa, p, 355.

${ }^{69}$ Ibid., p. 368.

${ }^{70}$ Chris Bennett: Three Frigates. The South African Navy comes of Age (Durban, Just Done, 2006), p. 178.
} 
blocks the blow [at Cuito Cuanavale] and with his right - strikes [in the west]". ${ }^{71}$ The South Africans were, after all, totally unprepared for a possible invasion of Namibia. All the conventional warfare formations were engaged at Tumpo. The only units the SADF had available on short notice to counter an invasion, were some lightly armed counter-insurgency infantry battalions and a few troops of obsolete Eland armoured cars. ${ }^{72}$

Even the Americans were surprised by the size and nature of the Cuban deployment. In a meeting with South African officials in Cairo at the end of June 1988, one J. Woods of the US National Security Council ominously told the meeting - in the presence of Generals Magnus Malan and Jannie Geldenhuys - that

[t]hese were the best units Cuba had, they were armed with advanced equipment, were much tougher and of a higher calibre than any troops seen in Angola before. The troops involved in the southward movement were prepared to take advanced combat positions and were building airfields at Cahama and elsewhere. The main threat in South Western Angola was the full squadron of Mig-23's which had an aggressive posture and capacity.

Woods said that the Cuban units had with them 800 pieces of heavy armour, 400 pieces of light armour, 300 artillery and rocket launchers, 250 air defence weapons, 80 missile launchers, 60-70 fixed-wing aircraft, and 20-30 gunship helicopters. What were their intentions, Woods asked, and gave the US assessment:

It did not appear to be merely a blocking force to prevent South African troop movement into Angola. Initially the US had estimated that this was a political build-up so as to improve the negotiation posture at the talks. However the force had become too big for that to be the only reason and now it appeared to be an offensive force looking for a fight.

Woods outlined a possible four-point strategy, which the Cubans sought to implement:

- to advance to the border and occupy the Calueque border electrical installation;

\footnotetext{
${ }^{71}$ Piero Gleijeses: "Moscow's Proxy? Cuba and Africa 1975-1988 (Journal of Cold War Studies, 8/2, Spring 2006), p. 37.

${ }^{72}$ Cf. Breytenbach: The Buffalo Soldiers, p. 316.
} 
- to seek out South African Defence Force units in the border area of northern Namibia as a result of Castro's belief that South Africa could not absorb as many casualties as Cuba could;

- $\quad$ to take and occupy South African bases in SWA and drive South African forces further south, at the same time driving eastwards along Namibian roads to cut off UNITA from the rear; and

- to refocus the force currently in the Fifth Region against UNITA. The intentions of the Cuban thrust would become clearer by mid-July and those forces would be in the best shape for an attack by about mid-August.

He also said that the Cuban force consisted of between 8000 and 10000 men, augmented by 5000 to 10000 SWAPO fighters. ${ }^{73}$ The presence of several thousand armed SWAPO insurgents added to the threat. The area now being occupied by the Cubans, the Fifth Military Region, was exactly the territory which the South Africans had dominated for several years in order to prevent SWAPO infiltration into Ovambo. As the guerrillas were now integrated at battalion level with the Cubans, ${ }^{74}$ it became impossible for the South Africans to fight SWAPO inside Angola without tangling with an aggressive Cuban army.

It is no wonder to learn from the archival sources that the South Africans were caught off-guard by the Cuban advance. Already a few weeks before the US assessment, Pik Botha indignantly complained to the Angolans about the Cuban march, calling it "a major thrust" and saying that "South Africa was extremely concerned at this development". 75

We know today that the Cubans, in consultation with the Soviets, were never seriously planning to cross the border - although, for obvious reasons, they declined to state this publicly. ${ }^{76}$ Chester Crocker tried to pry the information from an influential Cuban official, Jorge Risquet Valdes, but the wily Cuban kept his jaws

\footnotetext{
${ }^{73}$ Aluka, Minutes of bilateral meeting between South African and US officials, Cairo, 24.6.1988. See repository at www.aluka.org/action/doBrowse?sa=hist\&t=2067\&br=taxcollections\%7Cpart-of\%7Ccollection-minor

${ }^{74}$ Breytenbach: The Buffalo Soldiers, p. 316.

${ }^{75}$ Aluka, Minutes of bilateral meeting between South African and Angolan officials, 13.5.1988. See repository at www.aluka.org/action/doBrowse?sa=hist\&t=2067\&br=taxcollections\%7Cpart-of\%7Ccollection-minor

${ }^{76}$ Shubin: The Hot 'Cold War', p. 111.
} 
firmly shut in order to keep the Americans and South Africans guessing. ${ }^{77}$ The problem is that nobody outside the Cuban and Soviet decision-making circles really knew what their intentions were. Would they stop at the Namibian border, or would they actually invade the territory?

It is clear that the SADF high command seriously had to prepare for the latter possibility, and for this reason, an entire armoured division was called up to counter a possible Cuban invasion. Moreover, the US Woods assessment apparently made an impression on the South African military. At a SADF planning meeting two weeks later, General Geldenhuys predicted that "South Angola would not be the battlefield in the event of an escalation of the military situation". Rather, "the north of South West Africa would be the battlefield, without Ruacana, Ondangwa and Oshakati being surrendered". Nevertheless, at the same meeting Minister of Defence Magnus Malan ordered that, if the Cubans crossed into Namibia, "we should be ready to attack points north of the border". He declared that plans had to be drawn up for this eventuality. ${ }^{78}$ If these plans were in fact drawn up, they, of course, never materialised, as the momentum of the negotiations overtook them.

The Chief of the Army, Lieutenant General "Kat" Liebenberg, was somewhat more circumspect in his analysis. The most likely Cuban approach, he reported, would be an advance up to the border, while SWAPO conventional units carried out raids inside Namibia. The "most dangerous enemy action" would be a full-scale divisional invasion with two brigades marching on Ondangwa, one on Oshakati and one on Ruacana. The Army's reaction was to prepare several strongpoints south of the border, while 61 Mech and 4 SAI were being readied to act as a mobile defence. "The philosophy of the defence plan is: What comes over [the border], must be cut off and destroyed," Liebenberg said. ${ }^{79}$

To be sure, South African Military Intelligence interpreted the Cubans' posture as "predominantly defensive to ensure Angolan territorial integrity and to aid the SWAPO terror onslaught". An invasion of Namibia was not considered likely, as the Cubans did not underestimate the SADF's prowess, and because it

\footnotetext{
${ }^{77}$ Gleijeses: "Moscow's Proxy? Cuba and Africa 1975-1988 (Journal of Cold War Studies, 8/2, Spring 2006), pp. 41-41; Crocker: High Noon in Southern Africa, p. 399.

${ }^{78} 61 \mathrm{Mech}, \mathrm{MS} / \mathrm{UG} / 309 / 1$, "Bevestigende notas oor vergadering op 4 Jul 88 oor ops en krygstuig-aangeleenthede met betrekking tot Noord-SWA en SuidAngola, 5.7.1988, paragraphs 2 and 8, at www.61mech.org.za/assets/files/mediafiles/9fd64391585bc48f4175475b10e 52f6557332834_1.pdf.

${ }^{79}$ Ibid, paragraphs $16-17$.
} 
would scupper the budding peace talks. According to "a Cuban general who defected to the US" (probably Air Force General Dafael del Piño), the Cubans would carry out "vengeance air attacks" on "targets like Ruacana and Ondangwa" if the SADF attacked them inside Angola. In addition, the USSR agreed to a US request to rein in the Cuban Air Force if the South Africans refrained from attacking the Cuban ground forces from the air. ${ }^{80}$

In the event, none of this materialised. The SADF executed Operation Excite, which comprised elements of $61 \mathrm{Mech}, 32$ Battalion and 201 Battalion. They crossed the border into Angola near the water works of Ruacana. At Techipa, they had a sharp clash on 26 June with a much stronger Cuban force, but neither wished to escalate the war again, and both forces withdrew. Geldenhuys was satisfied with how his troops stood up to the Cubans at Techipa, ${ }^{81}$ while Colonel Jan Breytenbach judged the Cubans to be tactically inexperienced and not as good as the South African forces. ${ }^{82}$

Castro reportedly was furious and proved the SADF intelligence exactly right when he ordered an air strike the next day to teach the South Africans a lesson. The result was a bomb attack on the South African troops guarding the Calueque water works in which 12 South African soldiers were killed. ${ }^{83}$ This was the last fight in the war.

On the diplomatic front things also progressed. According to Piero Gleijeses, who often bends over backwards to portray the Cubans in a positive light, the South Africans on 22 July 'accepted the Cubans' demands: In exchange for an immediate ceasefire, South Africa would withdraw all its troops from Angola by 1 September" ${ }^{84}$ The implication is that the South Africans caved in, forced by the Cubans' military and diplomatic pressure. Gleijeses does not mention the astonishing Angolan and Cuban about-turn regarding Cuban troops in Angola. On 24 June, Jorge Risquet still contemptuously rejected the South African demands that the Cuban troops leave Angola - "South Africa would not get around a conference table that which it failed to achieve on the battlefield". (His aggressiveness almost

${ }^{80} 61$ Mech, Chief Army - Sector 20 HQ, 24.6.1988, at www.61mech.org.za/assets/files/mediafiles/591ef93cf3c61a605f7d8be35a47 3f0e6d38d060_1.pdf.

${ }^{81}$ Ibid.

${ }^{82}$ Breytenbach: The Buffalo Soldiers, pp. 322-344.

${ }^{83}$ Piero Gleijeses: "Cuba and the independence of Namibia" (Cold War History 7/2, May 2007, p. 299).

${ }^{84}$ Gleijeses: "Moscow's Proxy? Cuba and Africa 1975-1988 (Journal of Cold War Studies, 8/2, Spring 2006), p. 43. 
derailed the whole peace process. $)^{85}$ Only two weeks later, Angolan General Antonio Dos Santos Franca suddenly stated that, while his country was not legally obliged to send the Cubans home, "Angola and Cuba had agreed voluntarily to the withdrawal of all Cuban troops from Angola". He was even prepared "to discuss a calendar for total Cuban troop withdrawal". The Cuban chief representative, Carlos Aldana - the combative Risquet having been left at home this time - made a remarkable speech in which he inter alia paid tribute to the "contribution made by SA to create the circumstances to find a responsible and serious settlement to the problem". He continued:

We understand that within the framework of the negotiations that we are currently holding, the question of the presence of the Cuban troops bears a relation to the implementation of Resolution 435. Leaving aside rhetoric, we must recognise that there is a linkage. If it is not shown in this document it will be part of it, because there is a linkage. We cannot deny that fact. ${ }^{86}$

Aldana then echoed a sentiment expressed previously by the senior South African official at the meeting, Foreign Affairs Director General Neil van Heerden, that the outcome of the negotiations had to be that no-one should be a loser. $\mathrm{He}$ continued, referring to the linkage, which his country had so long rejected:

At other junctures, as we perhaps engaged in controversies, we rejected the concept of linkage. The question was debated in a variety of international fora and the idea was that if Namibia is to be independent, Cuban troops will have to leave Angola. We rejected that and there was great polemics about this. Now we do not deny that if we were to reach a settlement, that settlement would involve the withdrawal of Cuban troops.

Aldana, too, said he was willing to discuss a calendar for the withdrawal, and even to have the withdrawal monitored. ${ }^{87}$

\footnotetext{
${ }^{85}$ Aluka, Minutes of a meeting between delegations from South Africa, Angola, Cuba and the US in Cairo, 24-25 June 198, p. 7. See repository at www.aluka.org/action/doBrowse?sa $=$ hist $\& \mathrm{t}=2067 \& \mathrm{br}=\mathrm{tax}-$ collections \% 7Cpart-of\%7Ccollection-minor

${ }^{86}$ Aluka, Minutes of a meeting between reprentatives from South Africa, Angola, Cuba and the USA, 11.7.1988, p. 10. See repository at www.aluka.org/action/doBrowse? $\mathrm{sa}=\mathrm{hist} \& \mathrm{t}=2067 \& \mathrm{br}=\mathrm{tax}-$ collections\%7Cpart-of\%7Ccollection-minor

${ }^{87}$ Ibid., pp. 10-11.
} 
This was the final breakthrough which led to the South Africans to accept the withdrawal of their own troops from Angola and Namibia and the New York accords being signed in December 1988. The war was finally over. Another one, that about mastery of the past, was about to begin. This was going be a war waged of words, but no less important than the actual fighting, because both had political power and influence as the prize. The former was politics continued by other means; the latter war continued by other means. And, as Clausewitz remarked, although the grammar may differ, the intrinsic logic does not. ${ }^{88}$

\section{Conclusion}

Three questions arose in the introduction to this article. One, what were the South African strategic and operational objectives in Angola in 1987-1988? Two, did the SADF want to take and occupy the town of Cuito Cuanavale? Three, to which extent did the South Africans reach their objectives? The answer is not to be found in unsubstantiated suppositions or in vague and unverifiable references. One gets nearer to an answer in the reminiscences of those who were actively involved, but for the purposes of this article these were ignored, as were books by authors sympathetic to the SADF. In the end, only the original documents themselves were relied on. Based on these, the following conclusions seem justified:

- The basic South African security strategy was defensive. In the process, the SADF often adopted an offensive posture at the levels of military strategy, operations and tactics. However, all things considered, Pretoria above all sought to safeguard the status quo.

- No confirmation of allegations that South Africa ever sought to overthrow the MPLA regime in Luanda by military means and put UNITA in its place $^{89}$ could be found. Proposals by General Magnus Malan in 1979 in

${ }^{88}$ Carl von Clausewitz: Vom Kriege, VIII/6B (Berlin, Ullstein, 1998), p. 683.

${ }^{89}$ Cf. Ronnie Kasrils: "Turning point at Cuito Cuanavale" (Mail \& Guardian, 23.4.2008); Isaac Saney: "African Stalingrad: The Cuban revolution, internationalism and the end of apartheid" (Latin American Persepctives 33/81, 2006), p. 101; Horace Campbell: "The Military Defeat of the South Africans in Angola" (Montly Review, April 1989, pp. 1-15); Edgar J. Dosman: "Countdown to Cuito Cuanavale: Cuba's Angolan campaign", in Gary Baines \& Peter Vale (eds.): Beyond the Border War. New Perspectives on Southern Africa's Late-Cold War Conflicts (Pretoria, University of South Africa, 2008), p. 211; Hedelberto López Blanch and Ian Liebenberg: "A view from Cuba: Internationalists against apartheid" (Journal for Contemporary History, 34/1, February 2009, p. 83); Piero Gleijeses: 
this regard were accepted by the State Security Council, but never implemented. The documents do suggest that Pretoria would not shed a single tear if the MPLA did fall, but they also suggest that Pretoria did not expect this to happen.

- Until 1985, the SADF's repeated operations inside Angola were aimed in the first place at SWAPO in order to disrupt SWAPO's capacity to infiltrate into Namibia. Clashes with FAPLA amounted, as it were, to collateral damage.

- Aid given to UNITA should be seen primarily in the light of the war against SWAPO. UNITA occupation of southeast Angola prevented SWAPO from activating an insurgency in a large part of the operational area in the north of Namibia. South Africa did not want to get sucked into a Vietnam-type quagmire in Angola from which it could not extricate itself. The experience of 1975-1976 was decisive in this regard.

- With the events of 1975-1976 in mind, Pretoria was very loath to become involved in the clash between FAPLA and UNITA in 1987. The SADF became involved hesitantly and incrementally, which proves that South Africa - at least at that stage - had no offensive plans on a security strategic level. The strategic objective was simply to keep UNITA alive, which was translated on an operational level into the objective to stop the FAPLA offensive.

- Even before the FAPLA offensive was finally stopped, President PW Botha ordered a change in the South African military strategy. Now FAPLA had to be hit so hard in a counteroffensive, that it would not be able to launch another offensive before the end of 1988. On the operational level, this was translated into an order to either destroy the FAPLA brigades east of the Cuito River or to drive them to the west bank.

- In various planning documents, Cuito Cuanavale was mentioned as a possible target for capture and occupation. This was nearly always done in the context of an advance west of the Cuito. In the same documents, this course was rejected, and nothing ever came of it.

- Cuito Cuanavale is mentioned at least once as a possible target in the context of an advance east of the Cuito. However, the rider was that the

"Moscow's proxy? Cuba and Africa 1975-1988" (Journal of Cold War Studies, 8/2, Spring 2006, p. 37). 
town had to fall virtually without a fight - confirming what General Geldenhuys repeatedly said after the war. ${ }^{90}$

- The orders for the final phase of the campaign were simple: Advance up to the eastern bank of the Cuito River, drive FAPLA across it, prepare the river as an obstacle, enable UNITA to stand on its own two feet, and withdraw.

- $\quad$ Measured against those orders, the SADF reached its objectives to a very large extent, but not entirely. FAPLA's offensive against Mavinga was totally shattered while its presence on the east bank of the Cuito was reduced to a single - albeit heavily fortified - toehold.

- $\quad$ FAPLA was able to launch its next offensive against UNITA only in 1990, which UNITA beat off on its own. President Botha's aim that FAPLA had to be hit so hard that it would not be able to go on the offensive again before the end of 1988, was thus reached.

- The claims that the SADF suffered a back-breaking reverse at Cuito Cuanavale cannot, therefore, be sustained by the facts. The Angolans lost hands down. The Cubans did relatively well in their march to the border, which was a very intelligent move. By all measures, the South Africans also did well.

- The books by Helmoed-Römer Heitman and Fred Bridgeland may be onesided in the sense that they had access only to SADF records and spokesmen. Nevertheless, their work is vindicated in detail by the archival documents consulted. One may agree or disagree with aspects of General Geldenhuys' interpretation of the facts in his memoirs, but his facts as such are totally in agreement with the picture emerging from the original sources.

These conclusions may not be to the liking of Cuban, Angolan and ANC politicians, or academics driven by political correctness. However, on the basis of

${ }^{90}$ Cf. Steenkamp: South Africa's Border War, p. 152; Marga Ley: "Jannie Geldenhuys: 'Ek en Castro het nie saamgesweer'” (Beeld, 12.11.1992); Geldenhuys: "Veterane van die koue oorlog, insluitend die dienspliggenerasie, oor waarheid en propaganda", at www.news24.com/Rapport/InDiepte/0,,752-2462_2447895,00.html; Geldenhuys: Dié wat gewen het, pp. 179 and 191; Geldenhuys: South Africa is fantastik, pp. 129-137. 
Scientia Militaria, South African Journal of Military Studies, Vol 38, Nr 1, 2010. doi: 10.5787/38-1-80

the records available, these are the only possible conclusions. Hopefully, they will serve to make a more informed public discourse possible. 